Available online at GSC Online Press Directory

GSC Biological and Pharmaceutical Sciences

e-ISSN: 2581-3250, CODEN (USA): GBPSC2

Journal homepage: https://www.gsconlinepress.com/journals/gscbps

(RESEARCH ARTICLE)

\title{
Phytochemical analysis, antioxidant and antimicrobial studies of ethanol extract of Coula edulis seed shell
}

\author{
Nkop Ekpeno Josiah *, Onisoman Chuks Zudonu and Charles Chima Onyeji \\ Department of Chemistry Federal College of Education (Tech), Omoku, Rivers State, Nigeria.
}

Publication history: Received on 03 March 2020; revised on 06 July 2020; accepted on 08 July 2020

Article DOI: https://doi.org/10.30574/gscbps.2020.12.1.0056

\begin{abstract}
The phytochemical constituents, antioxidant and antimicrobial potential ethanol extract of Coula edulis (C. edulis) were evaluated. The presence of anthraquinones, steroids phenols, alkaloid, flavonoids, saponins, tannins and deoxy-sugar were ascertained to justify the utilization of this plant in the treatment of diseases. The ethanol extract of Coula edules seed shell was also examined for antioxidant activities and against seven different isolates. Phytochemical profile of the ethanol extract of Coula edulis shell revealed the presence of terpenes, cardiac glycosides, monosaccharides and carbohydrates while alkaloids was found to be absent in the extract. The extract of Coula edules seed shell revealed a very strong antioxidant activity when compared to vitamin $\mathrm{C}$ and butylated hydroxytoluene. The antimicrobial result showed that at all concentrations of the seed extract, the growths with almost all the microorganisms were inhibited. The results confirmed high level of antioxidant and antimicrobial properties in ethanol extract of $C$. edulis contain due to the presence of phytochemical constituents in the plant.
\end{abstract}

Keywords: Olacaceae; Coula edulis; Phytochemicals; Antioxidant activity; Antimicrobial

\section{Introduction}

Coula edulis Baill belongs to the family of (Olacaceae) which consist of 250 species [2]. It is a tree with irregular and circumvented stem [7]. The plant usually produces flower in the month of January and May [6]. They can grow under plantation condition as a timber plant [5] also described the fruit as a nut, ellipsoidal in shape, being about 3-4 cm long with flesh 5-6 mm thick surrounding the kernel. It is locally known as "Ewômœ" in Gabon. Coula edulis Baill (African walnut) is a medium-sized, evergreen tree growing to a height of 25-30 cm with dense crown [6].

The fleshy fruit is always tasty but covered with a hard-thick shell which makes harvest of the nut difficult [6]. C. edulis is commonly known as African walnut or Gabon nut tree due to its edible seeds. The nut has agreeable taste resembling hazelnut or chestnut [6]. Nearly half of the weight of the fruit is oil. Fatty acids containing a large proportion of oleic acid and triacylglycerides were found in the oil [18]. The fresh seeds of $C$. edulis contain flour, starch, fat, potassium and phosphorus [4]. The digestibility property of $C$. edulis is due to the presence flavonoids $\{19]$.

Minquartynoic acid has been isolated from the Coula edulis [11]. The dried bark of $C$. edulis exhibits anticancer activity due to the presence of acetylenes [9]. The bark powder is normally used for dressing sores in equatorial Africa. The decoction is used for stimulating appetite and treatment of anemia [10]. The stem bark is used in the treatment of ulcers and the decoction mixture is also used in treatment of diarrhea and oral infections [8]. The present study was designed to investigate the phytochemical and antimicrobial potential of ethanol extracts of Coula edulis shell.

\footnotetext{
${ }^{*}$ Corresponding author: Nkop Ekpeno Josiah
} 


\section{Material and methods}

\subsection{Plant materials collection}

The Coula edulis shell was selected based on the traditional uses. It was collected in a farm land in Ikot Obio Inyang Etinan Local Government Area, Akwa Ibom State, Nigeria on December, 2016, bagged and taken to the laboratory. Identification of the species was carried out at the Department of Botany and Ecological Studies, University of Uyo, Akwa Ibom State.

\subsection{Processing of the plant material and extraction}

The plant sample was washed, air dried, powdered, kept at ambient temperature, and protected from light. The powdered sample was macerated or extracted with $70 \%$ ethanol for $72 \mathrm{hrs}$. The extract was concentrated to dryness under reduced pressure. The concentrates were lyophilized and stored in sterile vials at $4{ }^{\circ} \mathrm{C}$.

\subsection{Phytochemical screening}

\subsubsection{Phlobatannins}

The extract $0.5 \mathrm{~g}$ was boiled with 3 drops of formaldehyde plus 6 drops of dilute $\mathrm{HCl}$ and the temperature raise to a boiling point and allowed to cool. The precipitate formed was washed with hot water. A bulky red precipitate after washing indicated phlobatannins.

\subsubsection{Tannins}

The plants extract $0.25 \mathrm{~g}$ was stirred with $5 \mathrm{ml}$ of distil water and filtered. $5 \%$ of Ferric Chloride was added to the filtrate and observed. A blue-black precipitate form indicated the presence of tannins.

\subsubsection{Deoxy-sugars}

The plant extract $0.5 \mathrm{~g}$ was dissolved in $2 \mathrm{ml}$ of glacial acetic acid containing one drop of Ferric Chloride solution. It was under-laid with $1 \mathrm{~m}$ of Conc. Sulphuric acid. A violet ring at the interphase was observed indicating a preliminary positive test.

\subsubsection{Anthraquinones}

The extract $0.25 \mathrm{~g}$ was boiled with $5 \mathrm{ml}$ of $10 \%$ sulphuric acid and filtrated. The filtrate shaken with $2.5 \mathrm{ml}$ of Benzene, the Benzene layer separated out and half its own volume of $10 \% \mathrm{NH}_{4} \mathrm{OH}$ added. No pink, violet or red colour in ammonia phase indicating the absent of anthraquinones.

\subsubsection{Cardiac glycosides}

The plant extract $0.5 \mathrm{~g}$ was allowed to dissolve in $2 \mathrm{ml}$ of Chloroform. Conc. Sulphuric acid was added carefully to form a low layer. No reddish-brown colour at the interphase indicated the absent of cardiac glycosides.

\subsubsection{Test for saponins}

Frothing test: Exactly $0.5 \mathrm{~g}$ of the extract was dissolved in distilled water in a test tube. Frothing which persisted on warming was taken as preliminary evidence for saponins [1].

\subsubsection{Test for flavonoids}

A few drops of concentrated hydrochloric acid were added to a small amount of the extracts of the plant material. Immediate development of a red colour was taken as an indication of the presence of flavonoids [17].

\subsubsection{Test for terpenes}

To $5 \mathrm{ml}$ of the extract add $2 \mathrm{ml}$ of chloroform and $3 \mathrm{ml}$ of concentrated $\mathrm{H}_{2} \mathrm{SO}_{4}$ leading to the formation of a reddishbrown ring confirming the presence of terpenes [15]. 


\subsubsection{Test for alkaloids}

To $0.5 \mathrm{~g}$ of the extract was stirred with $5 \mathrm{ml}$ of the $1 \%$ aqueous $\mathrm{HCl}$ acid on a steam bath. A few drops of dragendorff's reagent were used to treat $1 \mathrm{ml}$ of the filtrate. Turbidity or precipitation with this reagent was taken as evidence for the presence of alkaloids [1].

\subsubsection{Antioxidant activity index (AAI)}

Antioxidant activity index based on DPPH was estimated by the method of Scherer and Godoy. A range of concentration from 0.8-100 $\mu \mathrm{g} / \mathrm{mL}$ was prepared for each extract. Ascorbic acid (vitamin C) and BHA were used as controls. Each sample was prepared in triplicate. Absorbance was measured at $517 \mathrm{~nm}$. Percentage inhibition was obtained by the following formula:

\%Radical scavenger activity $=[($ Absorbance of DPPH - Absorbance of sample $) /$ Absorbance of DPPH $] \times 100$

\subsection{Test microorganisms}

The test microorganisms used in this investigation included bacteria Bacillis subtiles, Staphylococcus aureus, Pseudomonas aeruginosa, candida albicans, salmonella spp, Aspergillus niger, S. aureus and Escherichia coli

\subsection{Antibacterial susceptibility testing}

Disc diffusion method was used to study susceptibility of bacteria against plant extracts [13]. Bacteria were grown in Muller Hinton broth (Liofilchem, Italy) for 18 to $24 \mathrm{~h}$. Each culture was then suspended in a sodium chloride solution $(\mathrm{NaCl}, 0.9 \%)$ to reach turbidity equivalent to that of the $0.5 \mathrm{MacFarland}$ standards [20]. Extracts were diluted in dimethyl sulfoxide to $100 \mathrm{mg} / \mathrm{mL}$. Previously each extract $(10 \mu \mathrm{L}$ ) was loaded onto each filter paper disc (Whatman No. 1). Muller Hinton agar was suspended in distilled water, heated until complete dissolution and was autoclaved at 121 ${ }^{\circ} \mathrm{C}$ and then poured into Petri dishes. The discs were placed on cultures and antimicrobial activity was estimated after incubation at $37^{\circ} \mathrm{C}$ for $24 \mathrm{~h}$, by measuring the diameter of inhibition zone.

\subsection{Positive and negative control}

Gentamicin $(10 \mu \mathrm{g} / \mathrm{mL})$ and tetracycline $(30 \mu \mathrm{g} / \mathrm{mL})$ were used as positive control for the tested bacterial strains. Sterilized distilled water and dimethyl sulfoxide were used as negative control.

\section{Results and discussion}

\subsection{Phytochemical profile}

The results of the phytochemical screening carried out on the ethanol extract of Coula edules seed shell were recorded as shown in Table 1. Preliminary phytochemical screening revealed the presence of Saponins, steroids, flavonoids, deoxy sugar, terpenes and phitobatamin in ethanol extract but alkaloids and Anthraquinones were absent. Several medicinal plants are used in traditional medicines for curing many diseases. Therefore, the ethnomedicinal usage of $C$. edulis is attributed to the high concentration of phenolic compounds. Phytochemical compounds are known for their antioxidant, antimicrobial and antifungal activities [12]; [3]. The presence of these secondary metabolites such as tannin, phenolic, triterpenoids, flavonoids and reducing sugars in C. edulis ethanol extract give credence to its local usage in the treatment of diarrhea, sexually related diseases and oral infections. The presence of phenolic compounds is also reported in the seed which account for the anti-allergenic, anti-inflammatory and anti-thrombotic properties [5].

The ethanol extract of Coula edules seed shell showed a very strong antioxidant activity when compared to vitamin C and butylated hydroxytoluene used as references. These extract has a potential antioxidant property which enable the seed extract to be use in the treatment of oxidative stress related diseases [4]. Antioxidant activity of the Coula edules seed shell is justified by the presence of phenolic and the flavonoids in the phytochemical constituents. These phytochemical constituents account for the use of this plant in folk medicine in the treatment of myriad diseases such as bacterial diseases, parasitic diseases and diarrhea [4]. 
Table 1 Results of the preliminary phytochemical screening.

\begin{tabular}{|c|c|}
\hline Constituents & Intensity \\
\hline Saponins & + \\
\hline Steroids & ++ \\
\hline Flavonoids & +++ \\
\hline Deoxy-sugar & +++ \\
\hline Terpenes & +++ \\
\hline Phitobatamin & ++ \\
\hline Alkaloids & - \\
\hline Anthraquinones & ++ \\
\hline Tannins & ++ \\
\hline
\end{tabular}

The alarming widespread of microorganisms in the recent years has cause serious health challenge to human race since the microorganisms has acquired drug resistance due to frequent use and misuse of antibiotics. Therefore, alternative approach is needed to fight antibiotic resistance bacteria from natural antimicrobial substances since they are found to be safer, less toxic, cheap and readily available. The antimicrobial activity of the ethanol extract of Coula edules seed shell was evaluated using standard conventional method. The study established that the various concentrations of the seed extract inhibited the growth with almost all the microorganisms used in the study. This justifies the availability of antimicrobial principle such as phenolic compounds in the Coula edules seed shell. The potential antimicrobial agent is considered based on their zone of inhibition obtained from agar well or disc diffusion method. In the present investigation results from ethanol extract of Coula edules seed shell showed strong antimicrobial activity at various concentration. Among them, highest zone of inhibition Coula edules seed shell of $13 \pm 0.8,12 \pm 0.7$ and $11 \pm 0.3$ at various concentrations was observed, respectively.

Table 2 Inhibition zone diameters ( $\mathrm{mm}$ ) produced by the ethanol extract of C. edulis seed shell

\begin{tabular}{lllllll}
\hline $\begin{array}{l}\text { Microbial } \\
\text { isolates }\end{array}$ & $\mathbf{0 . 0 5} \mathbf{~ m g / m l}$ & $\mathbf{0 . 1 0} \mathbf{~ m g} / \mathbf{m l}$ & $\mathbf{0 . 1 5} \mathbf{~ m g} / \mathbf{m l}$ & $\mathbf{0 . 2 0} \mathbf{~ m g} / \mathbf{m l}$ & Genta & Tetra \\
\hline S. aureus & $11 \pm 0.3$ & $9 \pm 0.0$ & $10 \pm 0.1$ & $7 \pm 0.1$ & $16 \pm 0.0$ & $18 \pm 0.1$ \\
B. subtiles & $11 \pm 0.3$ & $12 \pm 0.1$ & $9 \pm 0.2$ & $8 \pm 0.3$ & $18 \pm 1.0$ & $15 \pm 0.0$ \\
E. Coli & $8 \pm 0.1$ & $9 \pm 0.1$ & $7 \pm 0.10$ & $7 \pm 1.0$ & $14 \pm 0.6$ & $12 \pm 0.7$ \\
P.aeroginosa & $10 \pm 0.2$ & $7 \pm 0.3$ & $12 \pm 0.7$ & $8 \pm 0.1$ & $16 \pm 0.2$ & $18 \pm 1.0$ \\
S. spp & $7 \pm 1.0$ & $5 \pm 0.0$ & $9 \pm 0.2$ & $8 \pm 0.2$ & $12 \pm 0.0$ & $11 \pm .04$ \\
C. albicans & $10 \pm 0.7$ & $8 \pm 0.0$ & $13 \pm 0.8$ & $10 \pm 0.1$ & $16 \pm 0.7$ & $6 \pm 0.2$ \\
A. niger & $9 \pm 0.8$ & $5 \pm 0.2$ & $8 \pm 0.0$ & $10 \pm 0.2$ & $13 \pm 0.0$ & $14 \pm 0.1$ \\
\hline
\end{tabular}

\section{Conclusion}

Phytochemical compounds are known for their antioxidant, antimicrobial and antifungal activities. The concentrations of each of the metabolite as shown by the phytochemical screening synergistically contribute to the significant antioxidant potency of Coula edules seed shell. This is justified by the local usage of the plant in the treatment of oxidative stress related diseases. Phytochemical screening showed that the antioxidant and antibacterial activities of the ethanol crude extract of $C$. edulis depend on the presence of phytochemicals such as phenolic, terpenoids, steroids, phitobatamin, flavonoids and tannins. The crude ethanol extract of $C$. edulis can serve as a new lead antimicrobial and antioxidant agents. Further research is needed in the isolation and characterisation of the active principles present in the extract which could be used for pharmaceutical relevance. 


\section{Compliance with ethical standards}

\section{Acknowledgments}

The authors profoundly thank Mr Aniekan Akpapan of Chemistry Department, Faculty of Science Akwa Ibom State University, Akwa Ibom State, Nigerian. This research did not receive any specific grant from funding agencies in the public, commercial or not-for-profit sectors.

\section{Disclosure of conflict of interest}

The authors declare no conflict of interest.

\section{References}

[1] Adegoke AA, Iberi PA, Akinpelu DA, Aiyegoro OA and Mboto CI. (2010). Studies on phytochemical screening and antimicrobial potentials of Phyllanthus amarus against multiple antibiotic resistant bacteria. Int. J. Appl. Res. Nat. Prod, 3(3), 6-12.

[2] Akharaiyi FC. (2011). Antibacterial, phytochemical and antioxidant activities of Datura metel. Int J Pharm Tech Res, 3(1), 974-4304.

[3] Alabri THA, Al Musalami AHS, Hossain MA, Weli AM and Al-Riyami Q. (2014). Comparative study of phytochemical screening, antioxidant and antimicrobial capacities of fresh and dry leaves crude plant extracts of Datura metel L. J King Saud Univ Sci, 26(3), 237-43.

[4] Andzi-Barhé T, Massala KK, Engonga LCO and Lebibi J. (2015). Phytochemical studies, total phenolic and flavonoids content and evaluation of antiradical activity of the extracts of the leaves from Dischistocalyx sp. (Acanthacées). J Pharmacogn Phytochem, 3(6), 174-8.

[5] Baydar NG and Baydar H. (2013). Phenolic compounds, antiradical activity and antioxidant capacity of oil-bearing rose (Rosa damascena Mill.) extracts. Ind Crops Prod, 41, 375-80.

[6] Bukola C, Adebayo-Tayo and Kola KA. (2008). Antimicrobial Activities of Coula edulis. Research Journal of Medicinal Plants, 2, 86-91.

[7] Cédric SO, Louis-Clément OE, Joseph-Privat O, Cheikna Z, Edouard NE and Alfred TS. (2015). Ethnotherapy study, phytochemical screening and antioxidant activity of Antrocaryon klaineanum Pierre and Anthocleista nobilis G. Don. Medicinal plants from Gabon. Int J Adv Res, 3(5), 812-9.

[8] Cédric SO, Joseph-Privat O, Guy-Roger NA, Louis-Clément OE, Joel-Fleury DS and Edouard NE. (2016). Phytochemical screening, antioxidant and antimicrobial potential of stem barks of Coula edulis Baill. Pseudospondias longifolia Engl. and Carapa klaineana Pierre. from Gabon. Asian Pacific Journal of Tropical Disease, 6(7), 557-563.

[9] Dembitsky VM. (2006). Anticancer activity of natural and synthetic acetylenic lipids. Lipids, 41, 883-924.

[10] Duke JA. (2001). Hand Book of Nuts. 1st Edition, CRC Press, Boca Raton, 343.

[11] Fort DM, SR King, TJ Carlson and ST Nelson. (2000). Minquartynoic acid from Coula edulis. Biochem. Syst. Ecol, $28,489-490$.

[12] Hossain MA and Nagooru MR. (2011). Biochemical profiling and total flavonoids contents of leaves crude extract of endemic medicinal plant Corydyline terminalis L. Kunth. Pharmacogn J, 3(24), 25-30.

[13] Mandal M, Paul S, Uddin MR, Mondal MA, Mandal S and Mandal V. (2016). In vitro antibacterial potential of Hydrocotyle javanica Thunb. Asian Pac J Trop Dis, 6(1), 54-62.

[14] Naz R and Bano A. (2013). Phytochemical screening, antioxidants and antimicrobial potential of Lantana camara in different solvents. Asian Pac J Trop Dis, 3(6), 480-6.

[15] Obianime AW and Uche FI. (2008). The phytochemical screening and effects of methanolic extract of Phyllanthus amarus leaf on the biochemical parameters of male guinea pigs. J. Appl. Sci. Environ. Manage, 12 (4), $73-77$.

[16] Raponda-Walker A and Sillans R. (1961). [The useful plants of Gabon]. Paris: Paul Lechevalier, 614.

[17] Shahid-Ud-Duaula AFM and Anwarul BM. (2009). Phytochemical screening, plant growth inhibition, and antimicrobial activity studies of Xylocarpus granatum Malaysian. J. Pharm. Sci, 7(1), 9 - 21. 
[18] Tchiegang C, C Kapseu and M Parmentier. (1998). Chemical composition of oil from Coula edulis (Bail) NUTS. J. Food Lipids, 5, 103-111.

[19] Waterman PG, CN Mbi, DB McKey and JS Gartlan. (1980). African rainforest vegetation and rumen microbes: Phenolic compounds and nutrients and correlates of digestibility. Oecology, 47, 22-33.

[20] Weli AM, Al-Blushi AAM and Hossain MA. (2015). Evaluation of antioxidant and antimicrobial potential of different leaves crude extracts of Omani Ficus carica against food borne pathogenic bacteria. Asian Pac J Trop Dis, 5(1), 13-6.

\section{How to cite this article}

Nkop EJ, Onisoman CZ and Charles CO. (2020). Phytochemical analysis, antioxidant and antimicrobial studies of ethanol extract of Coula edulis seed shell. GSC Biological and Pharmaceutical Sciences, 12(1), 48-53. 